\title{
MODIFIED SINGLE-ZONE MODEL OF RADIATION RECUPERATOR WITH MICROFINNED SURFACE
}

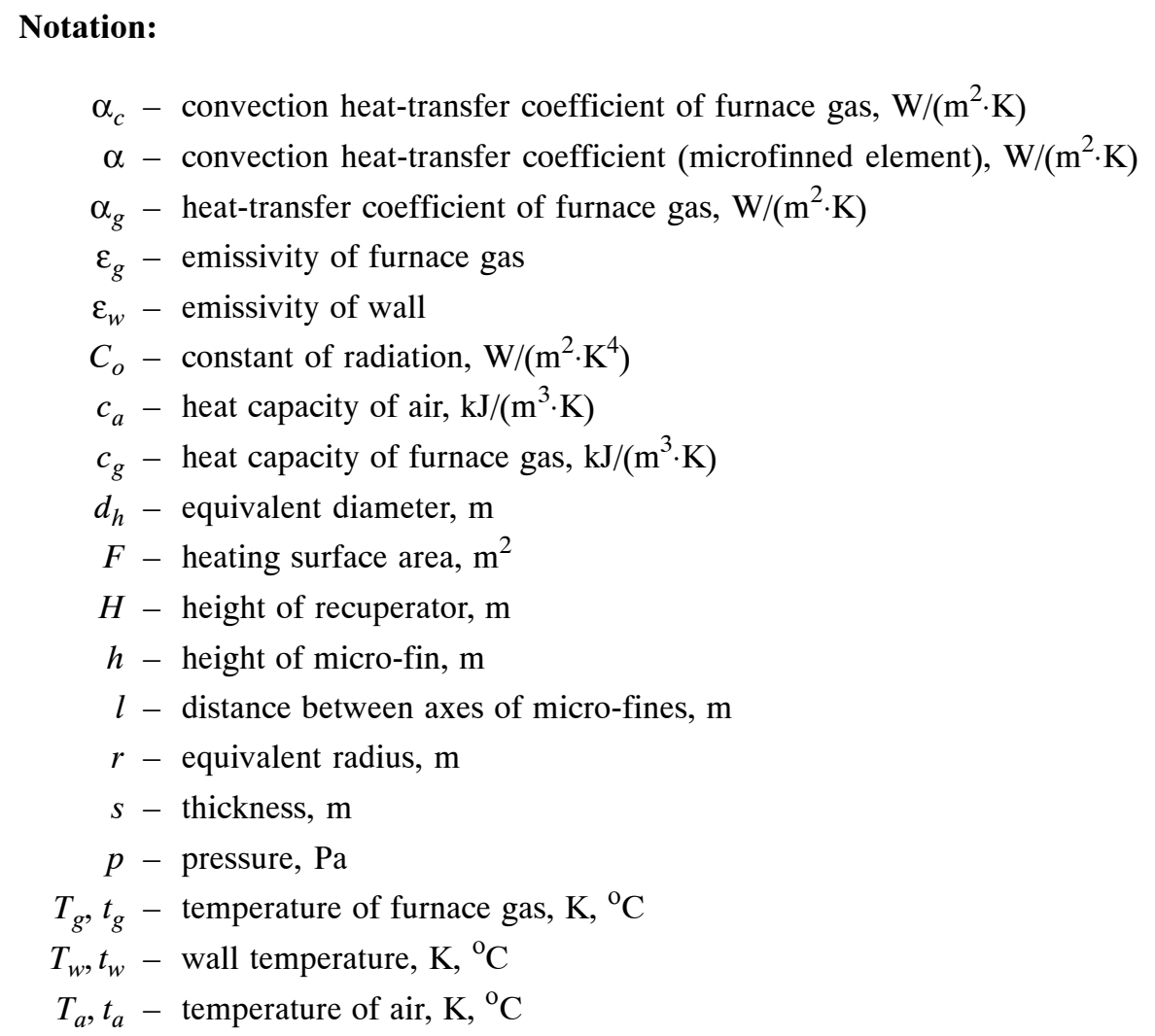

* Ph.D.: Faculty of Metals Engineering and Industrial Computer Science, AGH University of Science and Technology, Kraków, Poland; ztcios@agh.edu.pl 


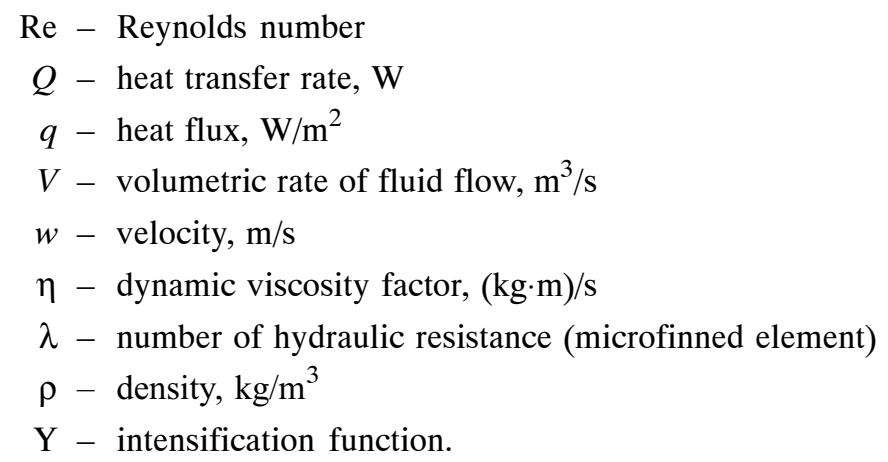

\section{INTRODUCTION}

Radiation recuperators are used for the recovery of heat from waste gases with industrial heat furnaces, glass furnaces and foundry ones [1, 3, 5, 12]. This type of recuperators may be used for furnaces that have waste gas temperature up to $1500^{\circ} \mathrm{C}$. The radiation recuperator have problems with heat transfer in air side.

The over-all heat-transfer coefficient in radiation recuperator is small, therefore intensification of heat transfer in air side is highly recommended. Especially effective method of intensification was microfinned surface of recuperator flow channels. On microfinned elements were carried out the model researches of heat transfer and hydraulic resistance. Applied researches [1, 2, 4, 6, 11, 13] zonal models [7, 8] and universal method of calculation [10] were elaborated. Single-zone model of radiation recuperator is a special case of zonal model.

This model is suitable to calculations of small overall dimensions radiation recuperators. The aims of this work are: modified single-zone mathematical model of radiation recuperator with microfinned air channel and the project by elaborated model of the radiation recuperator to glass furnace.

\section{THE MODIFIED SINGLE-ZONE MODEL}

The heat transfer in modified single-zone model of radiation recuperator with microfinned surface is describing by equations of heat balances and hydraulic resistance in recuperator. The wall temperature of microfinned centre tube is weighted mean temperature. This model includes equations (1) $\div(17)$.

The outlet furnace gas temperature from recuperator can be calculated by equation

$$
t_{g}^{\prime \prime}=\frac{\xi V_{g} c_{g}^{\prime} t_{g}^{\prime}-V_{a} c_{a}\left(t_{a}^{\prime \prime}-t_{a}^{\prime}\right)}{\xi V_{g} c_{g}^{\prime \prime}}
$$

where:

$$
\begin{aligned}
& V_{a}-\text { volumetric rate of air flow, } \\
& c_{a} \text { - heat capacity of air, }
\end{aligned}
$$




$$
\begin{aligned}
V_{g} & - \text { volumetric rate of furnace gas flow, } \\
c_{g}^{\prime}, c_{g}^{\prime \prime} & - \text { heat capacity of furnace gas, } \\
\xi & \text { - number of inner losses, } \\
t_{g}^{\prime} & - \text { furnace gas temperature inlet to recuperator, } \\
t_{a}^{\prime \prime} & - \text { air preheat temperature outlet, } \\
t_{a}^{\prime} & - \text { air temperature inlet. }
\end{aligned}
$$

The symbol $t_{a}$ denotes air arithmetic mean temperature:

$$
\bar{t}_{a}=\frac{t_{a}^{\prime}+t_{a}^{\prime \prime}}{2}
$$

The arithmetic mean temperature of furnace gas is:

$$
\bar{t}_{g}=\frac{t_{g}^{\prime}+t_{g}^{\prime \prime}}{2}
$$

The emissivity of furnace gas is described by equation [9] is:

$$
\varepsilon_{g}=\beta_{\mathrm{CO}_{2}} \varepsilon_{\mathrm{CO}_{2}}+\beta_{\mathrm{H}_{2} \mathrm{O}} \varepsilon_{\mathrm{H}_{2} \mathrm{O}}-\Delta \varepsilon_{g}
$$

where:

$$
\begin{aligned}
& \varepsilon_{\mathrm{CO}_{2}} \text { - emissivity of carbon dioxide, } \\
& \varepsilon_{\mathrm{H}_{2} \mathrm{O}} \text { - emissivity of water wapour, }
\end{aligned}
$$

$\beta_{\mathrm{CO}_{2}}, \beta_{\mathrm{H}_{2} \mathrm{O}}, \Delta \varepsilon_{g}-$ correction factors.

The effective emissivity of wall is expressed by [9] is:

$$
\varepsilon_{w}^{\prime}=\frac{\varepsilon_{w}+1}{2}
$$

The radiation heat-transfer coefficient is:

$$
\alpha_{r}=\frac{C_{o} \varepsilon_{w}^{\prime} \varepsilon_{g}\left[\left(\frac{T_{g}}{100}\right)^{4}-\left(\frac{T_{w}}{100}\right)^{4}\right]}{T_{g}-T_{w}}
$$

where:

$C_{o}$ - constant of radiation,

$T_{g}$ - temperature of furnace gas,

$T_{w}$ - weighted mean temperature of microfinned center tube. 
The heat-transfer coefficient of furnace gas is given by

$\alpha_{g}=\alpha_{r}+\alpha_{c}$

where:

$\alpha_{c}-$ convection heat-transfer coefficient on furnace gas-side [9] is:

$\alpha_{c}=\left(3.51+0.0031 \bar{t}_{g}\right) \frac{w_{g}^{0.8}}{d_{i}^{0.2}}$

$\bar{t}_{g}$ - arithmetic mean temperature of furnace gas,

$w_{g}$ - velocity of furnace gas inside center tube,

$d_{i}$ - inner diameter of center tube.

The convective heat-transfer coefficient to air (microfinned element) $[6,9]$ is:

$$
\alpha=(1+\mathrm{Y})\left(3.57+0.00174 \bar{t}_{a}\right) \frac{w_{a}^{0.8}}{\left(D-d_{i}\right)^{0.2}}
$$

where:

$\mathrm{Y}$ - intensification function,

$$
\mathrm{Y}=\frac{\alpha-\alpha_{o}}{\alpha}=36.52\left(\frac{l}{h}\right)^{0.35} \cdot e^{-0.037 \frac{l}{h}} \mathrm{Re}^{-0.36}
$$

$4000 \leq \operatorname{Re}<12000,5 \leq \frac{l}{h} \leq 40, h>h_{r}>0$,

$w_{a}$ - velocity of air,

$D$ - diameter of inner cover,

$d_{i}-$ diameter of center tube,

$l$ - micro-fin pitch,

$h$ - height of micro-fin,

$h_{r}-$ height of roughness.

The weighted mean temperature of microfinned center tube is:

$t_{w}=\frac{\alpha_{g} t_{g}+\alpha t_{a}}{\alpha_{g}+\alpha}$

The heat flux from furnace gas to wall is:

$q=C_{o} \varepsilon_{w}^{\prime} \varepsilon_{g}\left[\left(\frac{T_{g}}{100}\right)^{4}-\left(\frac{T_{w}}{100}\right)^{4}\right]$ 
The heat transfer rate is:

$Q=V_{a} c_{a} \Delta t_{a}$

The heating surface area is:

$F=\frac{Q}{q}$

The height of recuperator is:

$H=\frac{F}{\pi d_{i}}$

The pressure drop of air [6] is:

$\Delta p_{a}=\lambda \frac{w_{a}^{2} \rho_{a}}{2} \frac{H}{D-d_{i}}$

$\lambda=0.316\left(\frac{r}{h}\right)^{-0.76}\left(\frac{l}{h}\right)^{0.56} e^{-0.061 \frac{l}{h}}$

$2.67 \leq \frac{r}{h} \leq 16,5 \leq \frac{l}{h} \leq 40, h>h_{r}>0$,

where $r$ - equivalent radius.

\section{THE CALCULATIONS OF RADIATION RECUPERATOR} WITH MICROFINNED SURFACE

The radiation recuperator to glass furnace determine the following conditions:

- volumetric rate of furnace gas flow $V_{g}=3000 \mathrm{~m}^{3} / \mathrm{h}\left(0.83 \mathrm{~m}^{3} / \mathrm{s}\right)$

- furnace gas temperature inlet to recuperator $t_{g}^{\prime}=1150^{\circ} \mathrm{C}$

- concentration of carbon dioxide in furnace gas $\left[\mathrm{CO}_{2}\right]=9.0 \%$

- concentration of water vapour in furnace gas $\left[\mathrm{H}_{2} \mathrm{O}\right]=17 \%$

- number of inner losses $\xi=0.95$

- volumetric rate of air $V_{a}=2500 \mathrm{~m}^{3} / \mathrm{h}\left(0.69 \mathrm{~m}^{3} / \mathrm{s}\right)$

- temperature of hot air $t_{a}=500^{\circ} \mathrm{C}$

- diameter of center tube

$d_{i}=1.50 \mathrm{~m}$

- diameter of center cover

$D=1.54 \mathrm{~m}$ 
The outlet temperature of furnace gas

$$
t_{g}^{\prime \prime}=\frac{\xi V_{g} c_{g}^{\prime} t_{g}^{\prime}-V_{a} c_{a}\left(t_{a}^{\prime \prime}-t_{a}^{\prime}\right)}{\xi V_{g} c_{g}^{\prime \prime}}=\frac{0.95 \cdot 0.83 \cdot 1.62 \cdot 1150-0.69 \cdot 1.33(500-20)}{0.95 \cdot 0.83 \cdot 1.55}=842^{\circ} \mathrm{C}
$$

where:

heat capacity of furnace gas

$$
\begin{aligned}
& c_{g}^{\prime}=1.62 \mathrm{~kJ} /\left(\mathrm{m}^{3} \cdot \mathrm{K}\right), \\
& c_{g}^{\prime \prime}=1.55 \mathrm{~kJ} /\left(\mathrm{m}^{3} \cdot \mathrm{K}\right),
\end{aligned}
$$

heat capacity of hot air

$$
c_{g}=1.33 \mathrm{~kJ} /\left(\mathrm{m}^{3} \cdot \mathrm{K}\right) \text {. }
$$

The arithmetic mean temperature of furnace gas is:

$\bar{t}_{g}=\frac{t_{g}^{\prime}+t_{g}^{\prime \prime}}{2}=\frac{1150+842}{2}=996^{\circ} \mathrm{C}$.

The arithmetic mean temperature of air is:

$\bar{t}_{a}=\frac{t_{a}^{\prime}+t_{a}^{\prime \prime}}{2}=\frac{20+500}{2}=260^{\circ} \mathrm{C}$

The emissivity of furnace gas is:

- layer thickness

$s=0.9 \cdot d=0.9 \cdot 1.5=1.35 \mathrm{~m}$,

- emissivity of carbon dioxide

$(p \cdot s)_{\mathrm{CO}_{2}}=0.09 \cdot 1.35 \cdot 9.81=11.9 \mathrm{kPa} / \mathrm{m}$,

$\varepsilon_{\mathrm{CO}_{2}}=0.14$,

- emissivity of water vapour $\quad(p \cdot s)_{\mathrm{H}_{2} \mathrm{O}}=0.17 \times 1.35 \times 9.81=22.5 \mathrm{kPa} / \mathrm{m}$,

$\varepsilon_{\mathrm{H}_{2} \mathrm{O}}=0.16$,

- correction factors: $\quad \beta_{\mathrm{CO}_{2}}=1.0, \beta_{\mathrm{H}_{2} \mathrm{O}}=1.05, \Delta \varepsilon_{g}=0$.

$\varepsilon_{g}=\beta_{\mathrm{CO}_{2}}{ }^{\varepsilon_{\mathrm{CO}_{2}}}+\beta_{\mathrm{H}_{2} \mathrm{O}} \varepsilon_{\mathrm{H}_{2} \mathrm{O}}-\Delta \varepsilon_{g}=0.14+1.05 \times 0.16=0.31$.

The effective emissivity of center tube is:

$\varepsilon_{w}^{\prime}=\frac{\varepsilon_{w}+1}{2}=\frac{0.8+1.0}{2}=0.9$.

The radiation factor of furnace gas is:

$C_{o} \varepsilon_{w}^{\prime} \varepsilon_{g}=5.76 \cdot 0.9 \cdot 0.31=1.61 \mathrm{~W} /\left(\mathrm{m}^{2} \cdot \mathrm{K}^{4}\right)$. 
The radiation heat-transfer coefficient is:

$$
\begin{aligned}
\alpha_{r}=\frac{C_{o} \varepsilon_{w}^{\prime} \varepsilon_{g}\left[\left(\frac{T_{g}}{100}\right)^{4}-\left(\frac{T_{w}}{100}\right)^{4}\right]}{T_{g}-T_{w}}=\frac{1.61\left[\left(\frac{996+273}{100}\right)^{4}-\left(\frac{552+273}{100}\right)^{4}\right]}{996-552}= \\
=77.2 \mathrm{~W} /\left(\mathrm{m}^{2} \cdot \mathrm{K}\right) .
\end{aligned}
$$

The velocity of furnace gas inside center tube is:

$$
w_{g}=\frac{\dot{V}_{g}}{\frac{\pi d^{2}}{4}}=\frac{0.83}{\frac{\pi \cdot 1.5^{2}}{4}}=0.47 \mathrm{~m} / \mathrm{s}
$$

The convection heat-transfer coefficient is:

$$
\alpha_{c}=\left(3.5+0.0031 \bar{t}_{g}\right) \frac{w_{g}^{0.8}}{d^{0.2}}=(3.5+0.0031 \cdot 996) \frac{0.47^{0.8}}{1.5^{0.2}}=3.4 \quad \mathrm{~W} /\left(\mathrm{m}^{2} \cdot \mathrm{K}\right) .
$$

The heat-transfer coefficient of furnace gas is:

$\alpha_{g}=\alpha_{r}+\alpha_{c}=77.2+3.4=80.6 \mathrm{~W} /\left(\mathrm{m}^{2} \cdot \mathrm{K}\right)$.

The equivalent diameter of air gap is:

$d_{h}=D-d_{i}=1.54-1.50=0.04 \mathrm{~m}$.

The velocity of the air is:

$$
w_{a}=\frac{\dot{V}_{a}}{\frac{\pi D^{2}}{4}-\frac{\pi d^{2}}{4}}=\frac{0.69}{\frac{\pi}{4}\left(1.54^{2}-1.5^{2}\right)}=7.2 \mathrm{~m} / \mathrm{s} .
$$

The convection heat-transfer coefficient to the air (smooth element) is:

$$
\alpha_{o}=\left(3.57+0.00174 \bar{t}_{a}\right) \frac{w_{a}^{0.8}}{d_{h}{ }^{0.2}}=(3.57+0.00174 \cdot 260) \frac{7.2^{0.8}}{0.04^{0.2}}=37.1 \quad \mathrm{~W} /\left(\mathrm{m}^{2} \cdot \mathrm{K}\right) .
$$

The density of the air

$$
\rho=\rho_{o} \frac{p}{p_{o}} \frac{T_{o}}{T}=1.27 \frac{273}{273+260}=0.65 \mathrm{~kg} / \mathrm{m}^{3},
$$


where:

$\rho_{o}=1.27 \mathrm{~kg} / \mathrm{m}^{3}, p_{o}=1000 \mathrm{kPa}, T_{o}=273 \mathrm{~K}, p / p_{o}=1.0$.

The Reynolds number in the air gap is:

$$
\operatorname{Re}=\frac{w d_{h} \cdot \rho}{\eta}=\frac{7.2 \cdot 0.04 \cdot 0.65}{27.04 \cdot 10^{-6}}=6923,
$$

where:

$w_{a}=7.2 \mathrm{~m} / \mathrm{s}, d_{h}=0.04 \mathrm{~m}, \mathrm{c}=27.04 \cdot 10^{-6} \mathrm{~kg} /(\mathrm{m} \cdot \mathrm{s})$.

Substituting the value $\operatorname{Re}=6923$ and $l / h=10$ into equation (10) we get:

$\mathrm{Y}=36.52 \cdot 10^{0.35} \cdot e^{-0.037 \cdot 10} \cdot 6923^{-0.36}=2.3$.

The heat-transfer coefficient of microfinned element is:

$\alpha=\alpha_{o} \cdot(1+\mathrm{Y})=37.1 \cdot(1+2.3)=122.4 \mathrm{~W} /\left(\mathrm{m}^{2} \cdot \mathrm{K}\right)$.

The wall weighted temperature of microfinned center tube is:

$t_{w}=\frac{\alpha_{g} t_{g}+\alpha t_{a}}{\alpha_{g}+\alpha}=\frac{80.6 \cdot 996+122.4 \cdot 260}{80.6+122.4}=552^{\circ} \mathrm{C}$.

The heat flux from furnace gas to wall is:

$q=C_{o} \varepsilon_{w}^{\prime} \varepsilon_{g}\left[\left(\frac{T_{g}}{100}\right)^{4}-\left(\frac{T_{w}}{100}\right)^{4}\right]=1.61\left[\left(\frac{996}{100}\right)^{4}-\left(\frac{552}{100}\right)^{4}\right]=34293 \mathrm{~W} / \mathrm{m}^{2}$.

The heat-transfer rate of recuperator is:

$Q=V_{a}\left(c_{a}^{\prime \prime} t_{a}^{\prime}-c_{a}^{\prime} t_{a}^{\prime}\right)=0.69(1.33 \cdot 500-1.28 \cdot 20)=441.186 \mathrm{~kW}$.

The heating surface area is:

$F=\frac{Q}{q}=\frac{441186}{34293}=12.9 \mathrm{~m}^{2}$.

The height of recuperator is:

$H=\frac{F}{\pi d_{i}}=\frac{12.9}{\pi \cdot 1.5}=2.74 \mathrm{~m}$.

The radiation recuperator with microfinned surface illustrates Figure 1. 


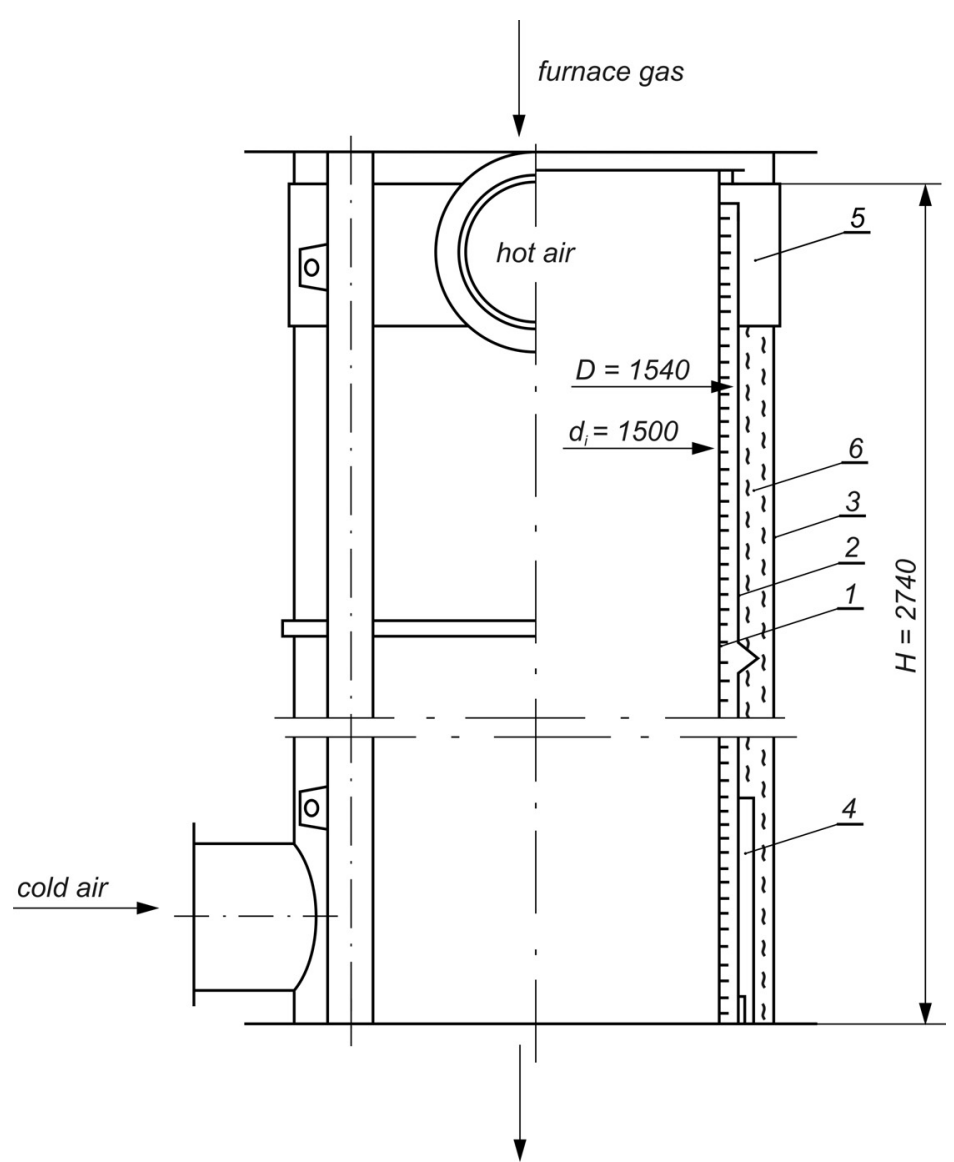

Fig. 1. Radiation recuperator: 1 - microfinned center tube, 2 -inner cover, 3-outer cover, 4 -inlet chamber, 5 -outlet chamber, 6 - heat insulation

The number of hydraulic resistance in air channel is:

$$
\lambda=0.316\left(\frac{r}{h}\right)^{-0.76}\left(\frac{l}{h}\right)^{-0.56} e^{-0.061 \frac{l}{h}}=0.316\left(\frac{0.02}{0.004}\right)^{-0.76} 10^{-0.56} e^{-0.061 \cdot 10}=0.18,
$$

where:

$$
\begin{aligned}
& r=0.02 \text { - equivalent hydraulic radius, } \\
& h=0.004 \text { - height of micro-fin, } \\
& l=0.04 \mathrm{~m} \text { - micro-fin pitch. }
\end{aligned}
$$

The pressure drop of air is:

$$
\Delta p_{a}=\lambda \frac{w_{a}^{2} \rho_{a}}{2} \frac{H}{D-d_{i}}=0.18 \frac{7.2^{2} \cdot 1.27}{2} \cdot \frac{2.74}{1.54-1.50}=406 \quad \mathrm{~Pa}
$$


where:

$$
\begin{aligned}
w_{a}=7.2 \mathrm{~m} / \mathrm{s} & - \text { velocity of air, } \\
\rho_{a}=1.27 \mathrm{~kg} / \mathrm{m}^{3} & - \text { density of air, } \\
p_{o} & =1000 \mathrm{kPa}, \\
T_{o} & =273 \mathrm{~K}, \\
H=2.74 \mathrm{~m} & - \text { height of recuperator, } \\
D-d_{i}=0.04 \mathrm{~m} & =\text { equivalent hydraulic diameter. }
\end{aligned}
$$

\section{INFERENCES}

- The heat transfer in modified simple-zone model of radiation recuperator with microfinned surface is describing by equations of heat flux balance referring to microfinned center tube.

- In the model were applied researches on convective heat-transfer coefficients and numbers hydraulic resistance of microfinned recuperator elements for ranges: $4200<\operatorname{Re}<12000,5<\frac{l}{h}<40,2.67<\frac{r}{h}<16, \quad h>h_{r}>0$.

- The modified model includes equations describing: heat-transfer coefficient of furnace gas, heat-transfer coefficient to air, weighted mean temperature of microfinned wall, mean temperatures: furnace gas and preheating air.

- The larger position of balance is heat flux from furnace gas to wall, therefore mean wall temperature can be described by weighted mean temperature.

- The single-zone model made possible the projects of small radiation recuperator with microfinned surface to glass furnaces.

\section{REFERENCES}

[1] Karczewski K.: Zeszyty naukowe AGH, Metalurgia i odlewnictwo, 16 (1990) 133

[2] Karczewski K.: Hutnik, 58 (1991) 172 $\div 174$

[3] Karczewski K.: Radiation Recuperators with Microfinned Surface. Int. Symp. Technical University of Kosice, 1994

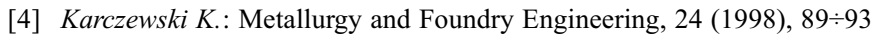

[5] Karczewski K.: Metallic Recuperators to Glass Tanks. Technical University of Kosice, Kosice, 1998

[6] Karczewski K.: Wpływ mikroużebrowania powierzchni równoległoprądowych rekuperatorów metalowych na ich cechy konstrukcyjne i eksploatacyjne. UWND AGH, Kraków, 2000

[7] Karczewski K.: Metallurgy and Foundry Engineering, 29 (2003), 97 $\div 107$

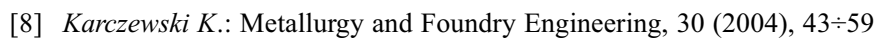

[9] Karczewski K.: Obliczenia cieplne rekuperatorów metalowych dla pieców przemysłowych. UWND AGH, Kraków, 2004, SU 1667

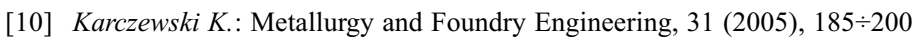


[11] Seo K., Kim V.: Int. J. Heat and Mass Transfer, 43 (2000), 2869 $\div 2882$

[12] Szargut J., Ziębik A., Kozioł J., Majza E.: Przemysłowa energia odpadowa. Zasady wykorzystania. Urządzenia. WNT, Warszawa, 1993

[13] Wang H.S., Honda H., Nozu S.: Int. J. Heat and Mass Transfer, 45 (2002), 1513 $\div 1523$

Received

September 2007 